J. Perinat. Med. 2 (1974) 243

\section{An attempt at blocking the cardiovascular and metabolic side-effects of beta-mimetic drugs during labor}

\author{
J. Esteban-Altirriba, A. M. J. Reñé, P. Durán, L. Cabero, E. Giralt, \\ M. Carreras, M. T. García-Cambronero
}

Servicio de Obstetricia y Ginecologia, Hospital de la Sta. Cruz y S. Pablo, Facultad de Medicina, Universidad Autónoma, Barcelona, Spain

Received November 22, 1973. Accepted April 16, 1974.

\section{Introduction}

Beta-mimetic drugs are currently used in obstetrics to treat several disorders: Threatened premature labor, hyperdynamic labor, or acute fetal distress $[2,5,6,7,8,12]$. Nevertheless the effectiveness of this treatment may be limited by the fact that the stimulation of the uterine receptors is not specific and is accompanied by the stimulation of the other beta-receptors distributed throughout the whole anatomy. For this reason, the desirable inhibition of the uterine activity is accompanied by the appearance of the undesirable side-effects. The most evident among them are those related to the stimulation of the cardiovascular beta-receptors (tachycardia, etc.). On the other hand, the stimulation of the metabolic beta-receptors, leads, as can be exepted, to an increase in the levels of blood glucose [8], 11.

By avoiding the cardiovascular and/or the metabolic effects of these drugs they could be used in those cases in which a preexisting pathology (heart disease, diabetes, etc.) might result in a serious deleterious situation. In some normal patients the need of high doses to obtain a suitable uterine effect, could result in a greater than usual development of the side-effects, thus making it desirable in these normal patients to supress them, at least, to some extent.

An ideal situation would be the possibility of obtaining specific stimulators for the receptor sites of different organs. But, up to the present time, nothing indicates a qualitative differentation

\section{Curriculum vitae}

Juan Esteban-Aitiririba was born in 1932 in Barcelona (Spain). Doctor of Medicine 1958, University of Barcelona, with the thesis "Comparative study of $\mathrm{O}_{2}$ saturation in maternal blood during pregnancy, labor and postpartum". In 1964 be founded a Department of Obstetrical research at the Hospital of S. Pablo in Barcelona. In 1968 be became Assistant Professor in Obstetrics and Gynecology and in 1972 Professor and Chairman at the Autonomons University of Barcelona (Department of Obstetrics and Gynecology). Besides scientific papers be bas written several obstetric bonks. At the present time the studies of bis group deal with the treatment of fetal acidosis.

among them. In consequence a specific uterine beta-mimetic drug does not exist.

For this purpose of avoiding this difficulty, Eskes et al. [4] in 1965 suggested the use of a beta-blocker with the aim of obtaining a cardiospecificity in the blockade, but for the reasons mentioned above, the possible existence of a site-specific blocker is also very doubtful. In fact, working with isoproterenol MAHON et al. [9] could not find the selectivity of beta-receptors in vessels and uterus.

At this point, the only possibility of interfering with the beta-mimetic effects at different levels would be the existence of differences either qualitative or quantitative in the competition 
between beta-mimetic and beta-blocker at the receptor binding site of the different organs.

This could explain the close relation existing between the cardiospecificity of some betablockers, claimed to be cardiospecific, and the doses used. That is, when used at therapeutical doses, they do not apparently evoke extracardiac effects, which appear only when the doses used result in a stimulation of the sites located in other organs.

The purpose of the present study is the search for a dose of a beta-blocker, being active at cardiovascular level without impairing the desired beta-mimetic effect at uterine level.

\section{Material and methods}

The present study was carried out on 12 patients in labor. The criteria for admission to the study were the following: 38-42 weeks of a normal pregnancy, normal maternal electrocardiogram, uterine activity over 100 Montevideo Units (M. U.), cervical dilatation between 3 and $5 \mathrm{~cm}$, ruptured membranes, cephalic presentation, a period of fasting of at least 8 hours, no medication before and during the investigation, and no signs of fetal distress.

In all cases the following variables listed with the corresponding methods were studied:

a) Intraamniotic pressure was registered using a Teflon open-tip catheter transvaginally inserted in the amniotic sac filled with saline and connecting its free end to a Statham pressure transducer.

b) Maternal heart rate (MHR) was obtained with a continuous cardiotachometric recorder, triggered by the $\mathbf{R}$ wave of the maternal electrocardiogram obtained with skin electrodes.

c) Maternal electrocardiogram (MECG) was also continuously recorded.

d) Fetal heart rate (FHR) was obtained with a continuous electrocardiotachometer triggered by the $R$ wave of the fetal electrocardiogram, using a scalp electrode.

The above variables were recorded with a BECKMAN multichannel polygraph (R 4 II).

e) Maternal blood pressure was measured before, during and after the infusion of the drugs to the mother, using the indirect auscultatory method.

f) Fetal capillary pH. Fetal blood samples were obtained before, during and after the infusion of the drugs to the mother, by SALING's technique [9] using previously heparinized glass pipettes. The actual $\mathrm{pH}$ was determined immediately after obtaining the samples with a glass microelectrode (AsTrup-RADIOMETER).

g) Maternal $\mathbf{p H}$ of the antecubital venous blood was determined before, during and after the infusion of the drugs.
In some cases, as indicated in the description of the study, venous maternal and capillary fetal blood glucose levels were also determined using the glucose-oxidase method.

The drugs used were: Ritodrine $\mathrm{HCl}^{*}$ ) as beta-mimetic and Practolol**) as beta-blocker [1, 3]. The drugs were always administered in saline.

\section{Design of the study}

The present study on the possible use of a betamimetic drug in combination with a beta-blocker can be divided into four successive stages, the characteristics of each being determined by the suggestions arising from the results obtained in the preceding one.

\subsection{Stage 1}

The first stage was undertaken with the aim of elucidating any kind of deleterious side-effects of the administration of such a combination involved. A continuous infusion of the betamimetic drug at doses inducing evident maternal tachycardia, (pulse rate $20 \%$ or more over the previous values) was given to the mother. During prolonged infusion, the beta-blocker was infused on two different occasions. The maximum dose of beta-mimetic used was $600 \mathrm{mcg} / \mathrm{min}$ and the infusion lasted 60 minutes. The infusions of the beta-blocker lasted 4 and 5 minutes and the total dose was $10 \mathrm{mg}$. This scheme was used in two cases.

\subsection{Stage 2}

Since no deleterious effects were recorded in this first group, we went further with two other patients in a second one, trying to determine the uterine activity and side-effects when the beta-mimetic was used together with the same dose of beta-blocker from the beginning, in the belief that the action of the beta-blocker on the uterine inhibition could be impaired by the great amount of beta-mimetic that reached the receptors in the doses and time administered to the first patients.

In order to test this effect the following scheme was designed: Two infusions of the beta-mimetic drug were given to every patient for two periods of 13 and 10 minutes. The lagtime between the

\footnotetext{
*) Pre-Par@ = DU-21220 (PHILIPS-DUPHAR, The Netherlands).

**) Eraldin ${ }^{*}=$ ICI-125 (ICI-FARMA, S. A., Spain).
} 
two infusions was the period necessary for reaching the previous values in MHR and FHR. The second infusion was accompained by an infusion of beta-blocker at a dose of $1 \mathrm{mg} / \mathrm{min}$. In this group we measured the same variables as in the first, but in addition, determinations of fetal and maternal blood glucose were performed before and after the administration of each infusion.

\subsection{Stage 3}

The encouraging results obtained in this group, particularly in respect to glucose levels in fetus and mother suggesting a possible inhibition of the beta-mimetic effects, prompted us to continue the investigation of the metabolic effects. In order to support these findings the second part of the protocol described above was applied to six other patients, using lower doses of the betamimetic drug. It consisted of a continuous infusion of the beta-mimetic (Ritodrine, $250 \mathrm{mcg} /$ min for 10 minutes) in combination with the beta-blocker (Practolol, $1 \mathrm{mg} / \mathrm{min}$ for the same time). The results showed a complete blockade of the beta-mimetic effects, even the desired one and suggested the possibility of an overdose of the beta-blocker (only maternal and fetal glucose showed a pattern of beta-mimetic effect).

\subsection{Stage 4}

To elucidate that point, we repeated the same scheme on two other patients, but using a dose of $0,5 \mathrm{mg} / \mathrm{min}$. for the beta-blocker.

Since the results obtained in this last group do not show a definite trend and might be considered controversial, they will be discussed in the "discussion" in more detail.

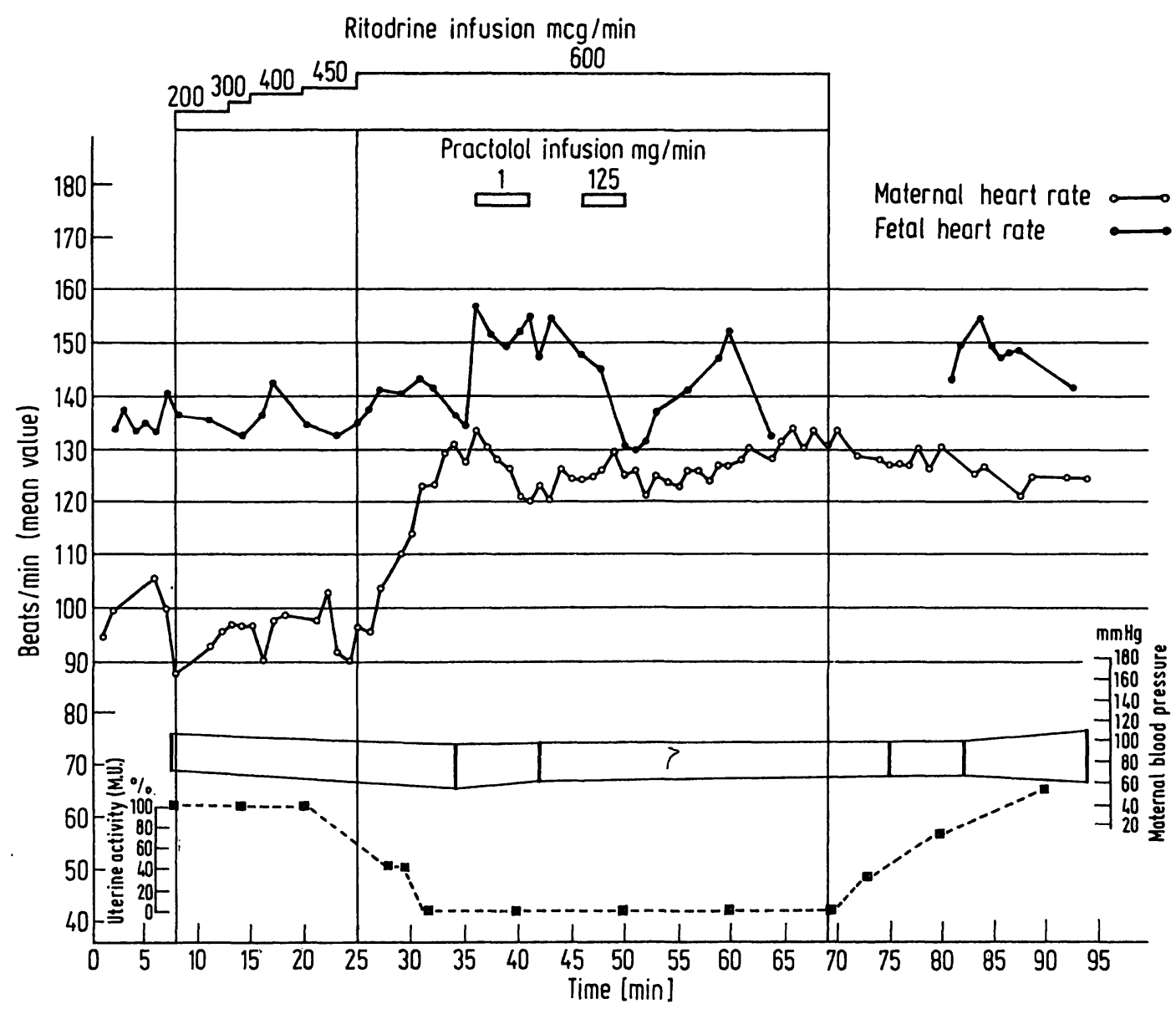

Fig. 1. Case corresponding to the first group of the study. Administration of incrcasing doses of Ritodrine lead to the typical effects of the drug. The administration of the beta-blocker infusions modified the cardiovascular effects, but he uterine activity did not resume. 


\section{Results}

\subsection{Group 1}

As can be seen in Fig. 1 the administration of increasing doses of Ritrodine (from $200 \mathrm{mcg} / \mathrm{min}$ to $600 \mathrm{mcg} / \mathrm{min}$ ), leads to the typical effects of the drug, that is maternal tachycardia (from 90100 beats $/ \mathrm{min}$ to $120-130$ beats $/ \mathrm{min}$ ), fetal tachycardia (from 130 - 140 beats/min to 150 160 beats/min), slight increase in the maternal blood pressure (from $35 \mathrm{mmHg}$ to $40 \mathrm{mmHg}$ ) and a complete inhibition of the uterine motility. When the beta-blocker was given, the maternal tachycardia decreased (from 134 beats/ $\mathrm{min}$ to 120 beats/min), specially for the first administration. There was no significant modification in the maternal pressure. Twelve minutes after the beginning of the first beta-blocker infusion, FHR also decreased (from 155 beats/min to 130 beats/min). Lastly, the uterine activity did not resume.
From the biochemical point of view we have not observed significant changes in maternal and fetal $\mathrm{pH}$. On the other hand, no pathological changes in the MECG were found. Concerning these parameters, similar results were found in the cases of all the groups.

\subsection{Group 2}

Fig. 2 shows the results of the second scheme of treatment. The first Ritrodrine infusion produced maternal tachycardia that rose from a previous value of 88 beats $/ \mathrm{min}$ to 118 beats $/ \mathrm{min}$, when $600 \mathrm{mcg} / \mathrm{min}$ of the beta-mimetic drug was infused. Also a slight fetal tachycardia appeared (from 124 beats/min to around 132 beats/min). There was no change in the differential blood pressure. Uterine motility was completely inhibited.

When the Ritodrine infusion was repeated in combination with the Practolol infusion, MHR did not increase as previously. In fact, it changed

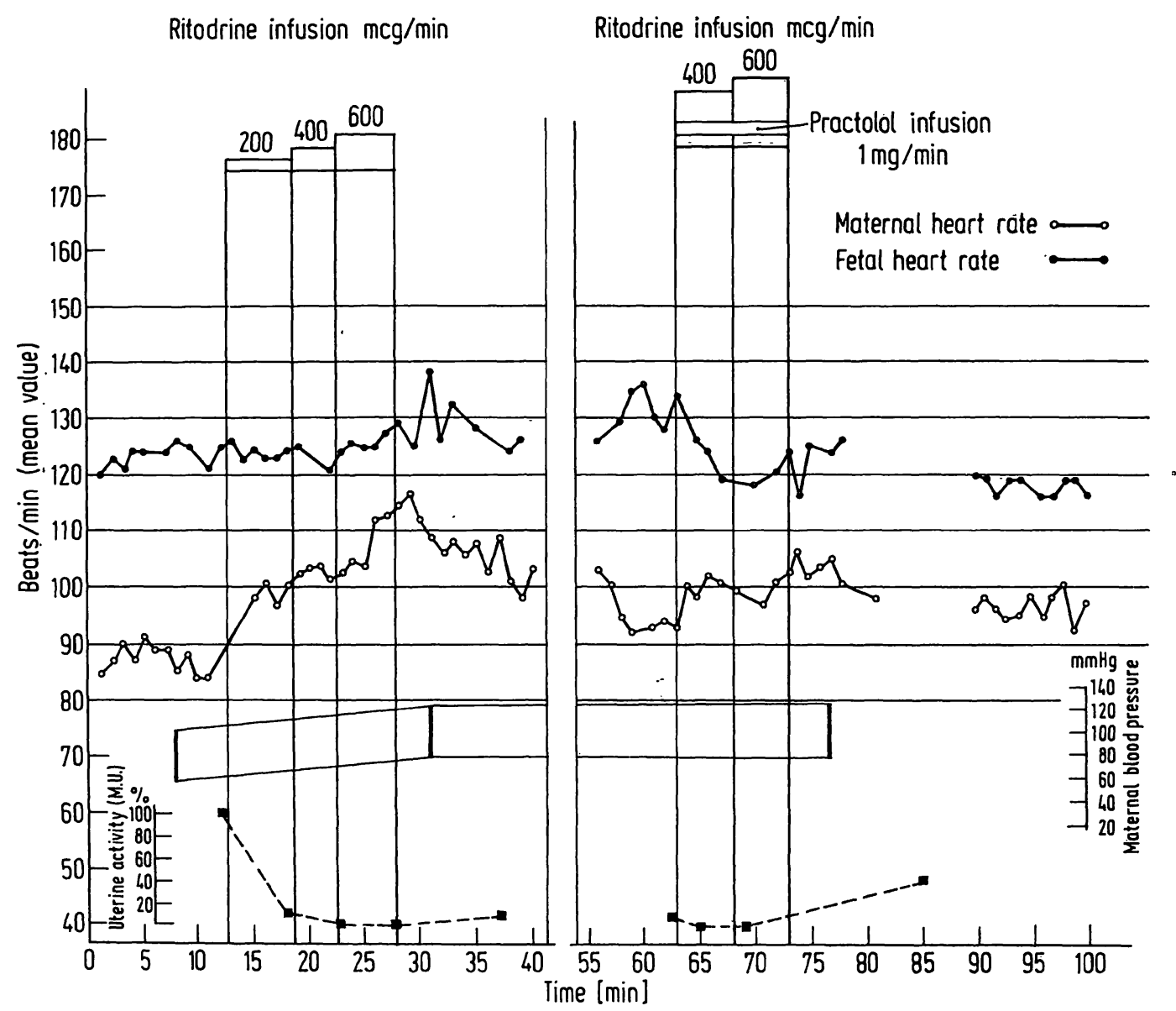

Fig. 2. When the combination of the beta-mimetic with the beta-blocker was given to the mother, the cardiovascular effects of the first drug were limited. 


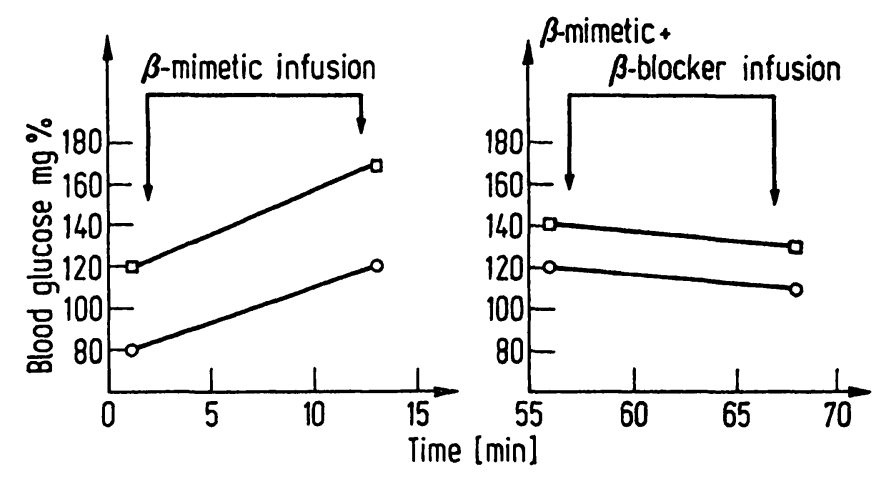

- Mother ofetus

Fig. 3. The beta-mimetic infusion produced a significant increase in the maternal and fetal blood glucose, but when the drug was given in combination with the beta-blocker the glucose levels decreased.

from 92 beats/min to a maximum of 106 beats/ min. FHR, that had not returned to the values recorded before the first Ritodrine infusion, decreased considerably when the combination of drugs was given to the mother (from 140 beats/ min to 118 beats/min). There was no modification in maternal blood pressure and uterine motility did not resume. It is necessary to say that in the cases of this group, the second part of the scheme was started before the uterine activity reached its previous values.

Fig. 3 shows the results obtained in the blood glucose levels in the mother and fetus. As can be seen, the beta-mimetic infusion leads to an important increase in the two values (from $120 \mathrm{mg} \%$ to $165 \mathrm{mg} \%$ in the mother, and from $80 \mathrm{mg} \%$ to $120 \mathrm{mg} \%$ in the fetus).

When the same dose of beta-mimetic drug was given to the mother simultaneously with the beta-blocker, the maternal and fetal blood glucose decreased from $140 \mathrm{mg} \%$ to $130 \mathrm{mg} \%$ in the mother, and from $120 \mathrm{mg} \%$ to $110 \mathrm{mg} \%$ in the fetus.

\subsection{Group 3}

Fig. 4 shows the absence of the beta-mimetic effect on MHR, FHR and uterine motility, when the Ritodrine infusion was simultaneously given to the mother with $1 \mathrm{mg} / \mathrm{min}$ of Practolol; that is the blockade of the beta-mimetic effects.

Nevertheless, the typical increase in maternal blood glucose induced by the beta-stimulation appeared in 5 out of the six cases studied, as shown in Fig. 5 (mean previous value = $73.3 \mathrm{mg} \%$; mean values $30,60,90$ and 120 minutes later $=82.0,81.6,80.0$ and $91.3 \mathrm{mg} \%$ respectively).

An increase in fetal blood glucose was found in all cases, as shown in Fig. 6 (mean previous value $52.6 \mathrm{mg} \%$; mean values $30,60,90$ and $120 \mathrm{mi}-$ nutes later $=61.0,64.8,77.2$ and $83.3 \mathrm{mg} \%$ respectively).
Fig. 4. The combination of clinical doses of Ritodrine $(250 \mathrm{mcg} /$ min) with $1 \mathrm{mg} / \mathrm{min}$ of Practolol lead to a complete blockade of the beta-mimetic effects on MHR, FHR and uterine motility.
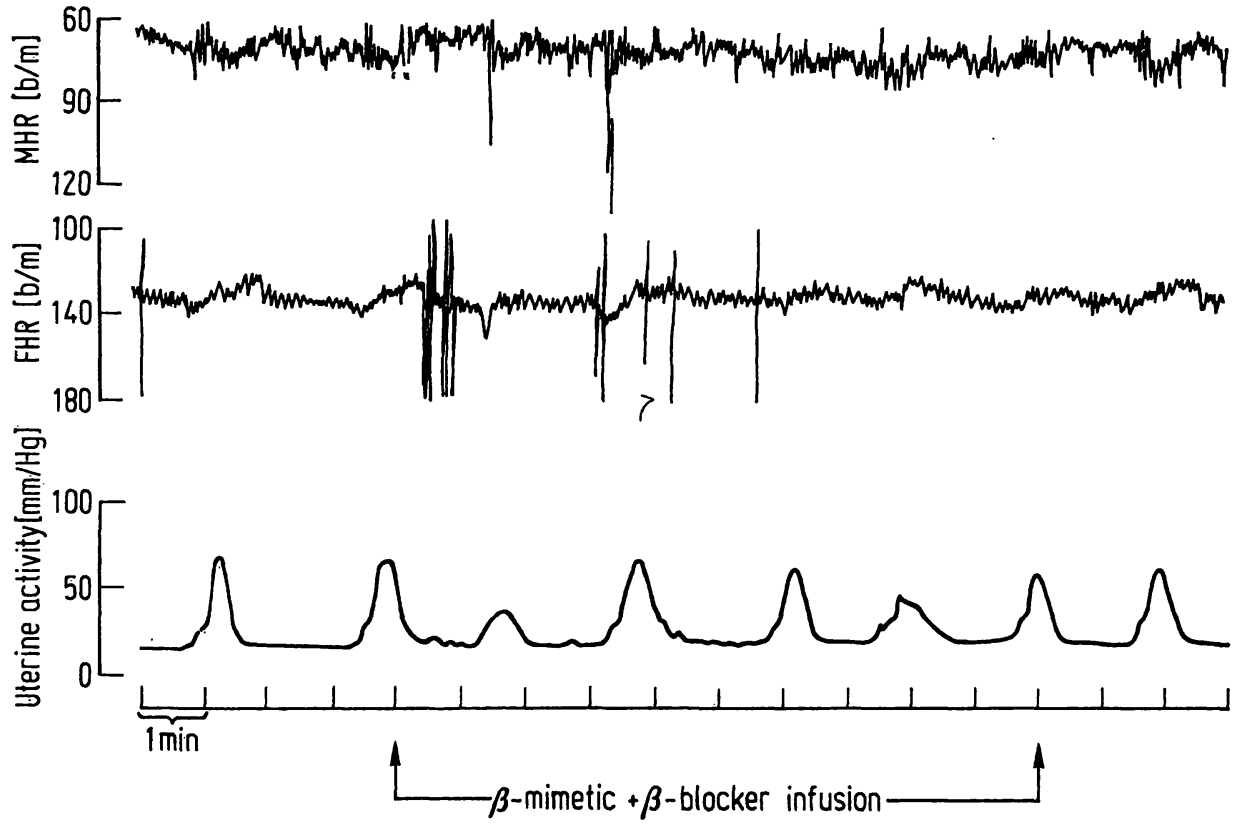


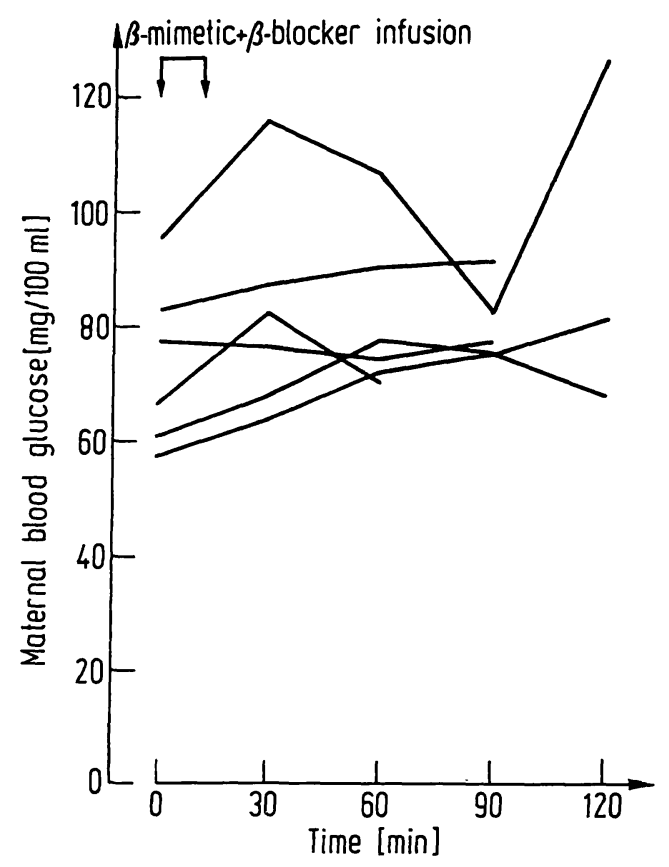

Fig. 5. The combination of clinical doses of Ritodrine : $(250 \mathrm{mcg} / \mathrm{min})$ with $1 \mathrm{mg} / \mathrm{min}$ of Practolol lead to the typical increase in maternal blood glucose induced by the beta-stimulation, in 5 out of the 6 cases studied. Individual values.

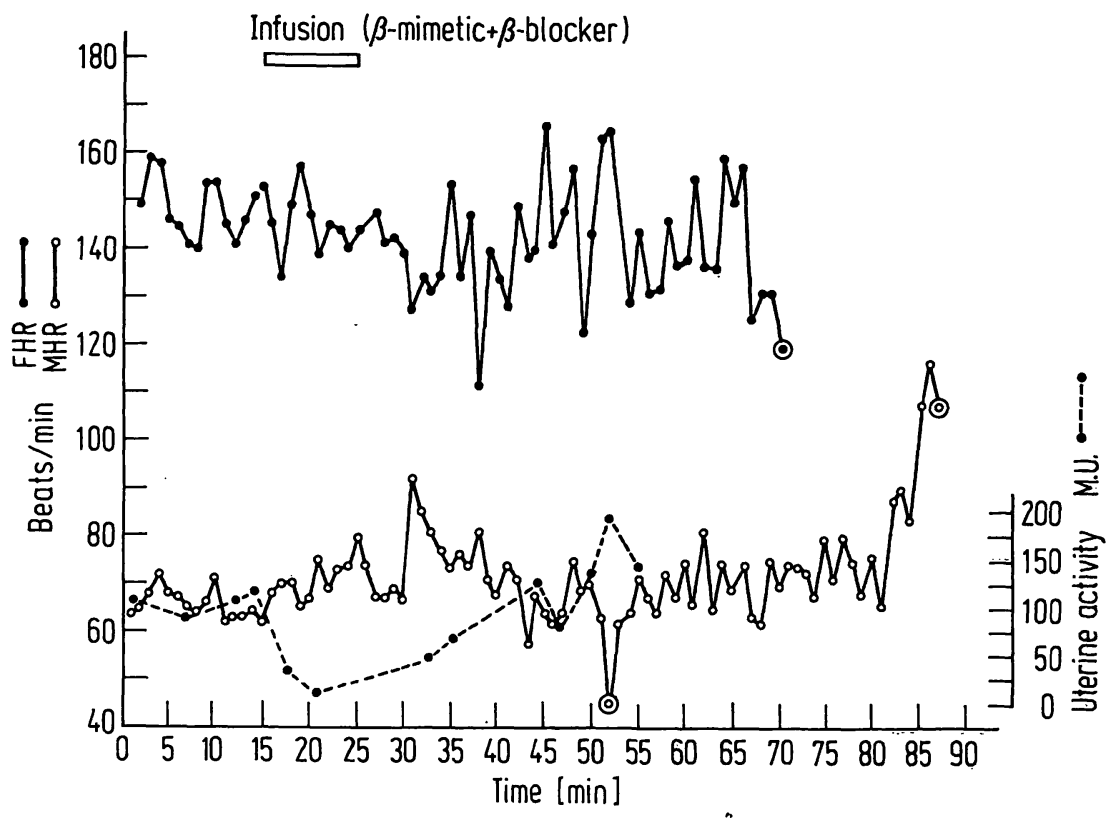

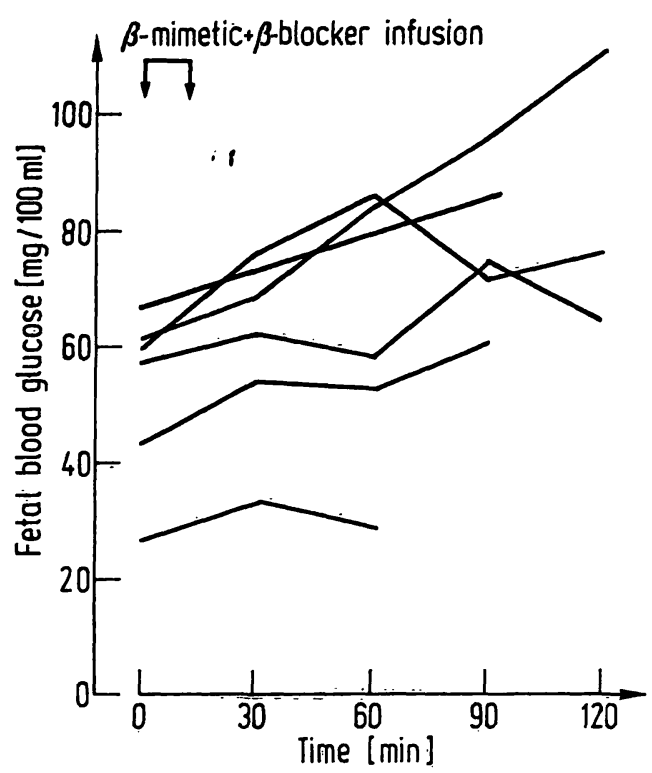

Fig. 6. The combination of $250 \mathrm{mcg} / \mathrm{min}$ of Ritodrine with $1 \mathrm{mg} / \mathrm{min}$ of Practolol lead to typical increase in fetal blood glucose induced by the beta-stimulation. Individual values.

\subsection{Group 4}

In one case (Fig. 7), during the infusion of the drug combination the uterine motility was inhibited (uterine activity before the infusion = 106.6 M.U.; uterine activity during the infusion $=30.0 \mathrm{M}$. U.; inhibition 64.7\%). Maternal and fetal tachycardia did not appear and maternal blood glucose did not show an important increase from the previous value during the first $60 \mathrm{mi}$ - nutes ( $73 \mathrm{mg} \%$ before the infusion and 74 and $75 \mathrm{mg} \%, 30$ and 60 minutes later), but rose to $100 \mathrm{mg} \%$ in 90 minutes.

In contrast, fetal blood glucose rose after the infusion ( $61 \mathrm{mg} \%$ before the infusion and 76 , 84 and $73 \mathrm{mg} \%$ 30, 60, 90 minutes. later).

Also in the other case, neither maternal or fetal heart rate showed tachycardia, with no evaluable change in the maternal blood glucose $(65 \mathrm{mg} \%$ 
before the infusion, $66 \mathrm{mg} \% 30,60$ and 90 minutes later, and $73 \mathrm{mg} \% 120$ minutes later), fetal blood glucose rose after the infusion $(55 \mathrm{mg} \%$ before the infusion and $63,61,65$ and $61 \mathrm{mg} \%$ $30,60,90$ and 120 minutes later), but uterine motility failed to be inhibited (Fig. 8 and 9).

Fig. 8. Second case from the group 4 in which also the combination of $250 \mathrm{mcg} / \mathrm{min}$ of Ritodrine with $0,5 \mathrm{mg} / \mathrm{min}$ of Practolol was given to the mother. In that case the uterine activity did not show the effect of the beta-stimulation.

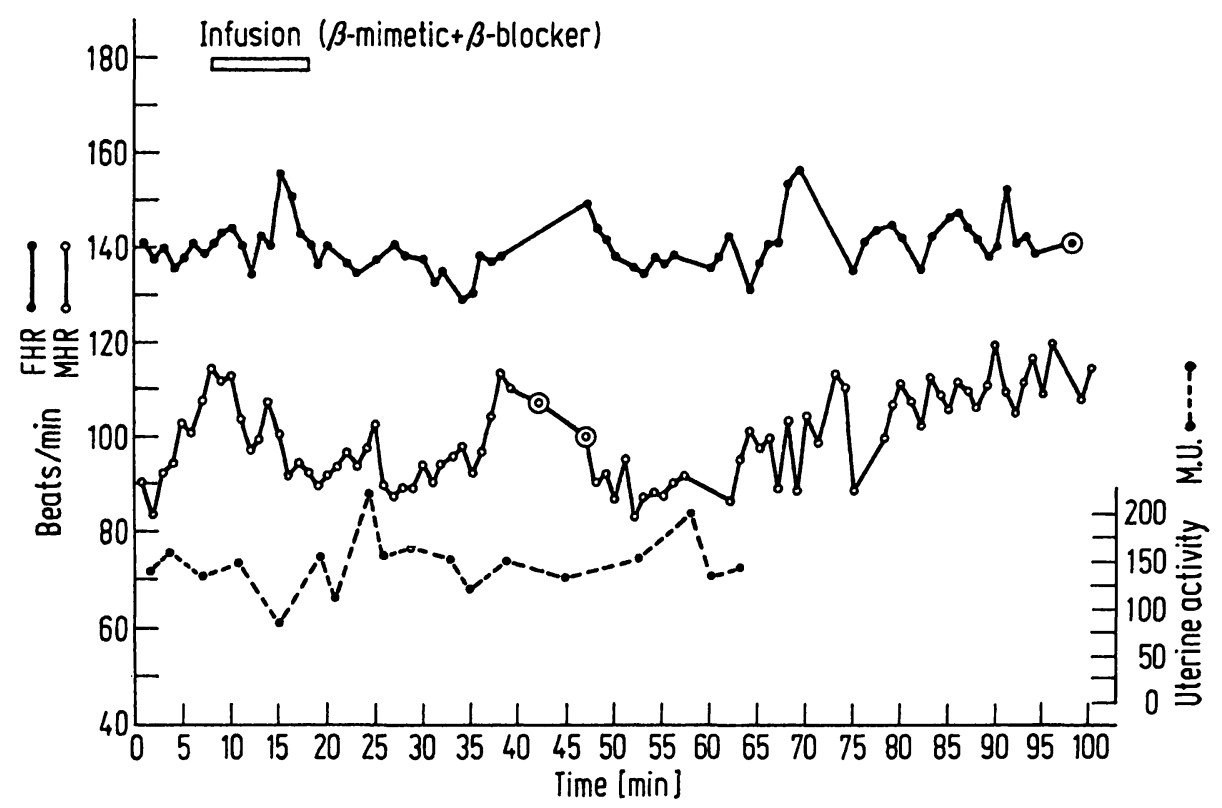

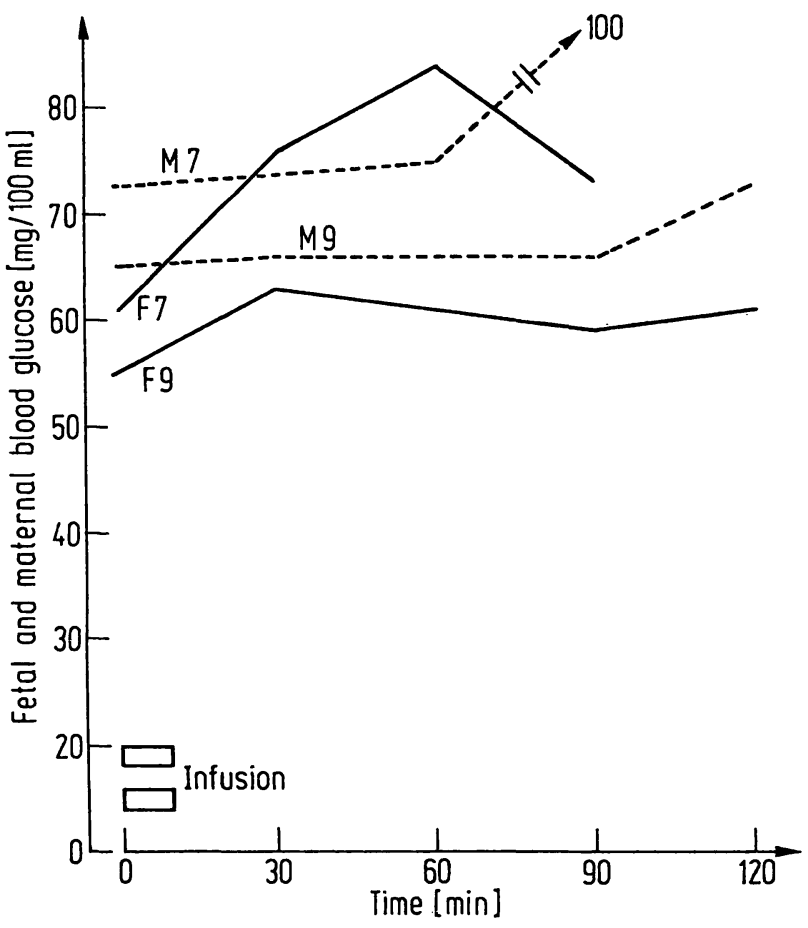

Fig. 9. Maternal and fetal blood glucose corresponding to the cases showed in Figs. 7 and 8. As can be seen, maternal blood glucose did not modify but fetal blood glucose increased under the effect of the drugs administered to the mother.

\section{Discussion}

As can be seen, the plan of the study has been rather unusual as the effects studied are in the obstetrical field. In fact, the association of a beta-mimetic and a beta-blocker might appear some what illogical. Since 1968, some articles $[1,3]$ have been published in claiming the cardiospecificity of certain beta-blocker agents. Although from these studies it was clear that this so-called cardiospecificity was mainly a "cardiopreference", it seemed interesting to us to give a new chance to the EsKes idea of blocking undersirable betamimetic effects in the use of these drugs in obstetrics.

For this reason the two first schemes were designed. The unusual high doses of betamimetic used in these schemes, may seem surprising but we believed that if the selectivity of the beta-blocker existed it would be also apparent in those doses. Since the beta-blocker can be a dangerous drug, it seemed safer to combine its use with its riatural antagonist which, when used in those doses, could prevent any kind of dangerous effect. In fact, as expected, the administration of the beta-blocker could counteract the beta-mimetic effects to some extent without impairing its uterine inhibition. These findings emphasised further the "cardiopreference" that gave rise to the study. Nevertheless, the two cases of the second treatment scheme showed that the 
beta-blocker was capable of inhibition. On the other hand, the fact that maternal and fetal blood glucose did not show the usual increase due to the beta-mimetic action, prompted us to continue the study.

When we tried to use the same doses of betablocker with clinical doses of the betamimetic drug we saw an almost complete disappearence of the beta-mimetic effects. Meanwhile, maternal and fetal heart rate maintained the normal values; in spite of the beta-mimetic infusion, the uterine activity (the main objective of the beta-mimetic treatment) was not inhibited. However, the metabolic effects of the beta-stimulation did not fail to appear.

These results lead to the conclusion that this dose of beta-blocker was able to compete at the level of cellular receptors with the beta-mimetic drug to an extent that overwhelmed this assumed preference. The logical inference was the need of decreasing the beta-blocker doses.

When with the same patient we used a dose of the blocker which was half that of the previous one, the hypothesis seemed to be confirmed.

In fact in that case we obtained a desirable uterine inhibition without maternal and/or fetal tachycardia. On the other hand maternal blood glucose did not change and only fetal blood glucose showed the beta-mimetic effect. That could be due to a lagtime in the effects of the beta-blocker administration to the fetus, and establish the proof of the possibility of a single metabolic response by the fetus to the betamimetic treatment without maternal variation in blood glucose.

When this experience was repeated in a second case all parameters behaved similarly, except uterine activity which was not inhibited. This raises the problem of individual responses.

\section{Summary}

The effectiveness of the use of beta-mimetic drugs in obstetrics may be limited by the fact that the stimulation of the uterine beta-receptors is not specific and is accompanied by the stimulation of the other beta-receptors elsewhere in the body. The ideal means of avoiding the cardiovascular and/or the metabolic effects of these drugs would be the possibility of obtaining specific stimulators for the different anatomical locations of the receptors. But, up to the present time, nothing indicates a qualitative
Since we are working with the competition at receptor level, the threshold between partial and total competition has to be very slight. For this reason an adequate dóse, established individually, would be necessary in the use of these drugs, and need to be investigated. However, another mechanism of action in the effect of the beta-blocker can not be excluded since its administration can impair the beta-mimetic effects obtained by the direct administration of cyclic AMP.

\section{Conclusions}

1. To our knowledge the administration of a beta-blocker together with a beta-mimetic to the mother during labor does not evoke deleterious side-effects either in mother or the fetus.

2. The so-called cardiospecific beta-blocker Practolol, has no cardiospecificity resulting in different responses in terms of inhibition of the beta-mimetic effects at metabolic and uterine levels.

3. It seems important to stress that, at least in two cases, fetal blood glucose rose under the effects of the beta-mimetic without any significant increase in maternal blood glucose. It supports the hypothesis that the increase in blood glucose observed in the fetus in these cases is due to a direct effect of the beta-mimetic drugs on the fetal metabolic receptors rather than a transplacental transfer of the maternal glucose.

4. The ability to compete with the beta-mimetic at receptors of some sites elsewhere in the body depends on an individual response to the different sites. It points out the impossibility of establishing fixed doses and limits the clinical use of the beta-blocker.

differentation among them and, in consequence, a specific uterine betamimetic drug does not exist.

For the purpose of avoiding this difficulty, Eskes et al. (1965) suggested the use of a beta-blocker with the aim of obtaining a cardio-specificity in the blockade.

The purpose of the present study is the search for a dose of a beta-blocker claimed to be cardio-specific, effective at the cardiovascular level but without impairing the desired beta-mimetic effect at the uterine 
level. The drugs used were $\mathrm{Ritodrine-} \mathrm{HCl}$ as beta-mimetic and Practolol as beta-blocker.

The study was carried out in 12 normal patients in labor, in which the following variables were studied: intraamniotic pressure, maternal heart rate, maternal electrocardiogram, fetal heart rate, maternal blood pressure, fetal capillary $\mathrm{pH}$, maternal venous $\mathrm{pH}$, maternal blood.glucose and fetal blood glucose.

The study was divided into four successive stages, the characteristics of each one being determined by the suggestions arising from the results obtained in the preceding one.

The results of the study show that the administration of the beta-blocker together with the beta-mimetic to the mother during labor does not evoke deleterious side-effects either in the mother or the fetus and that the so-called cardiospecific beta-blocker Practolol, as expected, does not have a cardiospecificity with different responses as to the inhibition of the beta-mimetic effects at metabolic and uterine levels (Figs. 1 to 5). The ability to compete with the beta-mimetic at the receptors of some anatomical areas depends on an individual response to the different areas; this points out the impossibility of establishing fixed doses and limits the clinical use of the beta-blocker.

Finally, from the study of the maternal and fetal blood glucose (Figs. 6 to 9), it appeared that, at least in some cases, maternal blood glucose did not change and only the fetal blood glucose showed the typical beta-mimetic effect. This fact supports the hypothesis of a single metabolic response by the fetus to the beta-mimetic treatment. I. e. the increase in blood glucose in the fetus is due to a direct effect of the beta-mimetic drug on the fetal metabolic receptors rather than a transplacental transfer of the maternal glucose.

Keywords: Beta-blocker, beta-mimetics, (metabolic and cardiovascular effects), glucose, mother, fetus, Practolol, Ritodrine.

\section{Zusammenfassung}

Ein Versuch, die kardio-vaskulären und metabolischen Nebenwirkungen beta-mimetischer Mittel unter der Geburt zu blockieren

Die Wirksamkeit von beta-mimetischen Mitteln in der Geburtshilfe ist durch den Umstand begrenzt, daß die Stimulation der Beta-Rezeptoren nicht spezifisch ist und daß sie mit Stimulation anderer Beta-Rezeptoren im Körper einhergeht. Im Idealfall könnten die metabolischen und/oder kardiovaskulären Nebenwirkungen dieser Mittel vermieden werden, falls spezifische Stimulatoren für die Rezeptoren in verschiedenen Organen zur Verfügung ständen. Jedoch ist ein qualitativer Unterschied noch nicht gefunden worden und ein uterus-spezifisches Beta-Mimetikum existiert folglich nicht.

EsKes et al. (1965) schlugen zur Vermeidung dieser Schwierigkeit vor, einen Beta-Blocker anzuwenden, um eine herz-spezifische Blockade $z u$ erreichen.

Unsere Arbeit versuchte, eine Dosis für einen angeblich herz-spezifischen Beta-Blocker zu bestimmen, bei welcher eine kardiovaskuläre Wirksamkeit bestand, ohne dabei die erwünschte Wirkung auf den Uterus zu vermindern. Die angewendeten Mittel waren Ritodrine- $\mathrm{HCl}$ als beta-mimetisches und Practolol als betablockierendes Mittel.

Die Versuche wurden an 12 Patientinnen mit Wehentätigkeit ausgeführt. Die folgenden Meßwerte wurden bestimmt: Intra-amniotischer Druck, mütterliche Herzfrequenz, EKG und Blutdruck, fetale Kapillar-pH-Wert mütterlicher venöser $\mathrm{pH}-\mathrm{Wert}$, mütterliche und fetale Blutglukose.
Die Untersuchung wurde in 4 aufeinanderfolgende Stadien aufgeteilt, wobei die Bedingungen für die folgende jeweils durch die Ergebnisse der voraufgehenden Stufe bestimmt wurden.

Es wurde festgestellt, daß die Verabreichung eines BetaBlockers zusammen mit dem beta-mimetischen Mittel an die Mutter unter der Geburt keinerlei schädliche Einwirkungen auf Mutter oder Kind hatte und daß - wie erwartet - der angeblich herz-spezifische Beta-Blocker Practolol keine Herzspezifität aufweist bezüglich unterschiedlicher Hemmungen der beta-mimetischen Wirkung auf Stoffwechsel und Uterus (Fig. 1-5). Die Fähigkeit, mit dem beta-mimetischen Mittel an den Rezeptoren in anderen Organen zu konkurrieren, ist von der individuellen Reaktion der verschiedenen Orte abhängig; dies zeigt auf, $\mathrm{da} ß$ es unmöglich ist, bestimmte Dosierungen festzusetzen und beschränkt den klinischen Gebrauch der Beta-Blocker.

Schließlich hat es den Anschein beim Verhalten der mütterlichen und fetalen Blutglukose (Figs. 6-9), da $\beta-\mathrm{zu}-$ mindest in Einzelfällen - die mütterliche Blutglukose sich nicht veränderte und nur der fetale Blutzucker einen typischen beta-mimetischen Effekt aufwies. Diese Tatsache untetstützt die Hypothese einer metabolischen Einzelreaktion auf die beta-mimetische Behandlung. Der fetale Blutzuckeranstieg beruht also auf einer Direktwirkung des beta-mimetischen Mittels auf die fetalen Stoffwechselrezeptoren und nicht auf einer transplazentaren Passage der mütterlichen Glukose.

Schlüsselwörter: Beta-Blocker, Beta-Mimetika, Fet, Herz-Gefäß-System, Mutter, Practolol, Ritodrine, Stoffwechsel.

\section{Résumé}

Un essai d'élimination des effets secondaires cardiovasculaires et métaboliques dus à l'utilisation des $\beta$ stimulants au cours du travail

L'efficacité des $\beta$-mimétiques en obstétrique, est souvent limité par le fait que leur activité sur les $\beta$-récepteurs utérins n'est pas spécifique et s'accompagne d'une stimulation des autres récepteurs, disséminés dans l'organisme tout entier. L'idéal, pour éliminer les effets cardiovasculaires et métaboliques de ces drogues, serait de stimuler les $\beta$-récepteurs de façon spécifique et préférenticlle, en 
fonction de leur situation topographique. Hélas, jusqu'à présent, rien ne nous permet de penser qu'il existe une différenciation qualitative parmi ces récepteurs et, en conséquence, il nous est impossible de profiter d'une éventuelle spécificité de l'utérus vis à vis des $\beta$-mimétiques. Afin de tourner cette difficulté, Eskes et coll. (1965) suggérèrent de neutraliser les effets secondaires cardiovasculaires des $\beta$-mimétiques en leur associant un $\beta$-bloquant à action spécifique cardiaque.

Le but de ce travail est de déterminer la dose de $\beta$ bloquant à utiliser dit cardiospecifique afin d'éliminer les effets secondaires des $\beta$-stimulants sans en supprimer les effets myorelaxants utérins. Les produits utilisés furent la Ritodrine, comme $\beta$-mimétique, et le Practolol, comme $\beta$-bloquant.

L'étude fut réalisée sur 12 patientes normales en travail. Les paramètres suivant furent étudiés: la pression intraamniotique, le rythme cardiaque maternel, l'électrocardiogramme maternel, le rythme cardiaque foetal, la pression sanguine maternelle, le $\mathrm{pH}$ capillaire foetal, le $\mathrm{pH}$ veineux maternel, les glycémies foetales et maternelles.

L'étude fut divisée en quatre étapes, les caractéristiques de chaque étape ultérieure étant déterminées en fonction des résultats obtenus au cours de l'étape précédente.
Les résultats de l'étude montrent que l'administration d'une association de $\beta$-bloquant et de $\beta$-stimulant à la femme en travail, n'entraine d'effets secondaires nocifs ni chez la mère, ni chez le foetus. Comme prévu, le Practolol ( $\beta$-bloquant soi-disant cardiospécifique), n'est pas cardiospecifique et provoque effects divertes du point de vue du métabolisme et de la motilite de l'uterus (Figs. 1-5). La capacité qu'ont les $\beta$-mimétiques d'agir en même temps, sur les récepteurs $\beta$ de plusieurs sites topographiques, dépend d'une sensibilité individuelle des différents sites. Ce fait explique l'impossibilité de déterminer les doses utiles et les limites d'utilisation des $\beta$-bloquants en clinique courante.

Enfin, de l'étude des glýcémies (Figs. 6-9), il apparaît que dans la plupart des cas, la glycémie maternelle ne change pas, seule la glycémie foetale se modifie sous l'influence spécifique de la substance $\beta$-mimétique. Ce fait soutient l'hypothèse de l'existence d'une réponse foetale seule, du point de vue métabolique, au traitement $\beta$ stimulant. Ceci suggère que l'augmentation de la glycémie foetale est due à un effet direct de la drogue sur le métabolisme hydrocarboné du foetus, plutôt qu'à un passage transplacentaire du glucose de la mère vers le foetus.

Mots-clés: $\beta$-mimétiques (effets métaboliques, effets cardiovasculaires), $\beta$-stimulants, glycémie, mère, foetus, Practolol, Ritodrine.

\section{Bibliography}

[1] BARret, A. M.: A cardioselective beta-receptor antagonist. Postgrad. Med. J. Suppl. 47 (1971) 7

[2] Caldeyro-Barcia, R., J. M. Magaña, J. B. Castillo, J. J. Poseiro, C. Mendez-Bauer, S. V. Pose, L. Escarcena, C. Casacuberta, J. R. Bustos, G. Grussr: A new approach to the treatment of acute intrapartum fetal distress. Perinatal Factors Affecting Human Development. Pan American Health Organisation. Washington, D. C., June 1969

[3] Dunlop, P., R. G. Shanks: Selective blokade of adrenoceptive beta-receptors in the heart. Br. J. Pharmac. Chemother. 32 (1968) 201

[4] Eskes, T. K. A. B., L. Stolte, J. Seelen, H. D. Moed, C. Vogelsang: Epinephrine derivates on the activity of the human uterus. II. The influence of Pronethalol and Propanalol on the uterine and systemic activity of p-hydroxy-phenylisopropyl- arterenol (Cc-25). Amer. J. Obstet. Gynec. 92 (1965) 871

[5] Esteban-Altirriba, J., O. Gamissans: Effects of isoxuprine, n-butyl-sympatol, Cc-25, Th-1165 and Ritodrine (Du-21220) upon myometrial activity and side-effects. Symposium "Utero inhibitory drugs and their effects on the mother, the fetus and the newborn". Punta del Este (Uruguay), 1970

[6] Esteban-Altirriba, J., O. Gamissans, P. Duran, J. Calaf, A. Reñe: Administration of beta-mimetic agents to the mother as a conservative therapy in cases of intrapartum fetal acidosis: In: SAIING, E.,
J. W. Dudenhausen: Perinatale Medizin Band III, 4. Deutscher Kongreß für Perinatale Medizin, Berlin 1971. Thieme, Stuttgart 1972

[7] Gamissans, O., J. Esteban-Altirriba, J. Calaf: The treatment of intrapartum fetal acidosis by intravenous infusion of beta-adrenergic drugs to the mother. In: Huntingford, P. J., R. N. BEARD, F. E. Hrtren, J. W. Scopes: Perinatal Medicine. 2nd European Congress of Perinatal Medicine. London 1970. Karger, Basel 1971

[8] Gamissans, O., M. Carreras, P. Duran, J. Cararach, J. Calaf, V. Abril, J. Esteban-Altirriba: The treatment of fetal acidosis with beta-mimetic drugs. Study on acid-base balance, blood glucose levels and uterine motility. In: Baumgarten, K., A. Wesselius de Casparis: Proceedings of the International Symposium on the treatment of the fetal risks. Baden, Austria, 1972. Produced by the University of Vienna, Medical School, Vienna 1973

[9] Mahon, W. A., D. W. J. Reid, R. A. DaY: The in vivo effects of beta-adrenergic stimulation and blockade on the human uterus at term. J. Pharmacol. Exper. Therap. 156 (1967) 178

[10] Saling, E.: Das Kind im Bereich der Geburtshilfe. Thieme, Stuttgart 1966

[11] Urban, G., K. Baumgarten, H. Baumung, A. Beck, H. Frolich, W. Gruber, A. Setol: Die Beeinflussung des Glukosetoleranztestes bei normalen Schwangerschaften mit Ritodrine und Th 1165 a. 
In: Baumgarten, K., A. Wesselius de Casparis: Proceedings of the international symposium on the treatment of the foetal risks. Baden, Austria, 1972. Produced by the University of Vienna, Medical School, Vienna 1973
[12] Wesselius de Casparis, A., M. Thiery, A. Yo Le Sian, K. Baumgarten, O. Gamissans, J. G. Stolk, V. VIVIER: Results of double-blind, multicenter study with Ritodrine in premature labour. Brit. Med. J. (1971) 144

Professor Dr. J. Esteban-Altirriba Servicio de Obstetricia y Ginecología Hospital de la Sta. Cruz y S. Pablo

Facultad de Medicina,

Universidad Autónoma

Avda. S. Ant. Ma Claret, 167

Barcelona/Spain 